\title{
Reconsidering the policy options to combat obesity
}

\author{
Christine Ferguson \\ From Metabolism, diet and disease \\ Washington, DC, USA. 29-31 May 2012
}

\begin{abstract}
As the prevalence of obesity steadily grows, so too does our understanding of the threats that excess weight poses to both our individual health and our nation as a whole. With this information, there is a need now more than ever to reconsider the options we have to mitigate the health risks and costs of this growing epidemic. This includes, among other conversations, examining how employers can play a role in encouraging healthier habits through workforce-based initiatives and a reconsideration of the riskbenefit paradigm that informs the decisions of payers, regulators, and providers on this crucial issue.
\end{abstract}

Submit your next manuscript to BioMed Central and take full advantage of:

- Convenient online submission

- Thorough peer review

- No space constraints or color figure charges

- Immediate publication on acceptance

- Inclusion in PubMed, CAS, Scopus and Google Scholar

- Research which is freely available for redistribution 